\section{EFFECT OF OESTROGENS ON MYOMETRIAL CONTRACTIONS}

BY

A. 1. KLOPPER, Ph.D., M.B., B.Sc., M.R.C.O.G. Scientific Staff, Medical Research Council

AND

\section{K. J. DENNIS, M.B., F.R.C.S.Ed., M.R.C.O.G.} Lecturer

From the Obstetric Medicine Research Unit (M.R.C.) and the Department of Midwifery, University of Aberdeen

Some observations by Jeffcoate (1938) originally suggested that oestrogens stimulated uterine contractions in women who developed secondary inertia during labour. From this the belief grew among some British obstetricians that the exhibition of oestrogens would in some way facilitate the onset of labour. In connexion with a survey of perinatal mortality undertaken by the National Birthday Trust we recently had the opportunity to examine a sample of obstetric records from all over the country. It was evident that the practice of giving oestrogens, either as a form of medical induction or as a preliminary to surgical induction, is widespread. It is unlikely that oestrogens will of themselves cause the onset of labour, but there is some evidence to suggest that they may increase uterine contractility, making the muscle more responsive to mechanical stimuli such as rupture of the membranes (Reynolds, 1949).

The work of Csapo (1956) shows that during pregnancy progesterone reduces myometrial contractility. Short and Moore (1959) have shown that at the onset of labour there is no fall in blood progesterone, nor according to Shearman (1959) does the output of urinary pregnanediol decline in the weeks before the onset of labour. It is possible that toward the end of pregnancy some endocrine factor which overcomes the progesterone block on myometrial contractility comes into play. During pregnancy large amounts of oestriol are excreted, and in a recent study it was shown that a sharp rise in oestriol excretion occurs toward the end of pregnancy (Klopper et al., 1961). It seemed possible, therefore, that this oestrogen in particular is concerned in bringing about an endocrine milieu in which the myometrium will respond to the mechanical stimuli which bring about labour.

In all the literature on the effects of oestrogen in labour we have been unable to find records of a trial controlled in accordance with modern statistical criteria. We therefore set out to test the efficacy of oestriol in such a trial. When the figures of this "double-blind" trial were analysed it became of interest to determine whether the results were peculiar to oestriol or would occur with other oestrogens also. This was therefore followed by a second, larger, trial in which the effects of oestriol were compared with those of a synthetic oestrogen, stilboestrol.

\section{Methods}

For the first trial a small homogeneous group of subjects who would show minimal variation in their obstetric performance was used. Women who were to be subjected to artificial rupture of membranes for clinical reasons were selected, but those with twins, hydramnios, antepartum haemorrhage, intrauterine foetal death, or previous caesarean section were excluded. The trial was limited to primigravidae under 30 years old who were withın 21 days of their expected date of delivery. Messrs. Organun kindly supplied us with tablets containing $10 \mathrm{mg}$. of oestriol and a set of identical placebo tablets. The tablets for each patient were dispensed in advance by our statistical section and none of the observers knew whether oestriol or placebo tablets had been given. Oral administration was started 24 hours before the rupture of membranes and continued until delivery. The dosage was two tablets $(20 \mathrm{mg}$.) initially. followed by one tablet $(10 \mathrm{mg}$.) six-hourly thereafter. A record of pussible side-effects such as vomiting or flushing was kept for each patient. but such occasional phenomena were equally distributed and it proved impossible to tell from the patient's clinical behaviour whether she was having oestrogen or not. The trial was discontinued and the code broken when 44 patients had been treated.

For the second trial a larger variety of patients was included and a greater number were studied in order to exclude chance concentrations of aberrant cases. The subjects in this trial were divided into four groups; (1) primigravidae 29 years old or younger: (2) primigravidae 30 years old or older; (3) women who had borne one or two viable children and were 29 years old or younger; and (4) women who had borne one or two viable children and were 30 years old or older. Equal numbers of women in each group were given oestriol, stilboestrol, or placebo tablets. The routine and dosage scheme for oestriol and placebo were organized as before. As stilboestrol is a very much more potent oestrogen than oestriol the stilboestrol tablets contained $5 \mathrm{mg}$., so that stilboestrol dosage was $10 \mathrm{mg}$. initially followed by $5 \mathrm{mg}$. six-hourly. Again it was not possible by clinical observation to tell which compound the patient was having. The hospital routine was not modified for patients included in the trial. If labour had not started 24 hours after the rupture of the membranes an intravenous "pitocin" drip was set up and such infusions were repeated on subsequent days if necessary. Decisions regarding operalıve intervention were made on the usual clinical grounds. the operator often being unaware of the fact that the patient was included in the trial. No eligible patients were excluded from the trial, the only selection factors being the omission of those with twin pregnancies, hydramnios, etc., as previously detailed. The second trial was discontinued and the code broken when 231 patients had been treated.

\section{Results}

In some instances the onset of labour with spontaneous rupture of membranes occurred after the start of medication and before surgical induction was performed. In the first trial this happened once in the oestriol group and five times in the control group. Thus 21 of the 22 patients given oestriol were submitted to surgical induction, and of the 22 patients given a placebo only 17 came to surgical induction. The results are summarized in Table I. If patients having a spontaneous rupture of membranes are excluded the inductiondelivery interval in the oestriol group was 16.2 hours and in the control group 21.2 hours.

The distribution of cases with respect to age, length of gestation, and birth weight is virtually identical, so that the two groups appear to be well balanced. The 
differences between the two groups were small and not statistically significant, but were enough to justify a larger trial; particularly seeking to establish whether the exhibition of oestriol or stilboestrol would reduce the incidence of cases requiring intravenous pitocin after surgical induction of labour.

The incidence of caesarean sections and of pitocin drips in the second trial is shown in Tables II and III. The induction-delivery interval and length of labour in each group, after all caesarean section cases and those having spontaneous rupture of membranes had been excluded, is shown in Table IV.

Statistical analysis of the data in these tables showed there to be no significant difference between the oestriol, stilboestrol, and control groups. This point is emphasized in the Chart, in which the induction-delivery interval for each group is plotted after exclusion of caesarean sections.

The antepartum oestrogen therapy did not have any evident effect on lactation, uterine involution, or lochia

TABle 1.-Administration of Oestriol or Dummy Tablets to

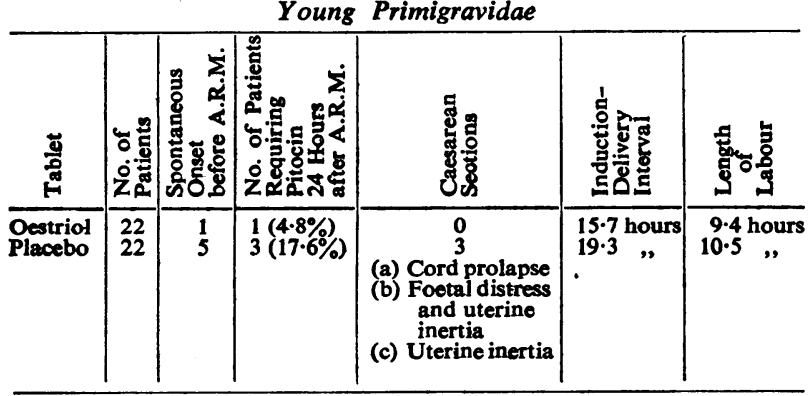

Table II.-Caesarean Sections in Second Oestrogen Trial

\begin{tabular}{|c|c|c|c|c|c|}
\hline \multirow{2}{*}{ Tablet } & \multirow{2}{*}{$\begin{array}{c}\text { No. } \\
\text { of } \\
\text { Women }\end{array}$} & \multirow{2}{*}{$\begin{array}{c}\text { Spon- } \\
\text { taneous } \\
\text { Onset } \\
\text { before } \\
\text { A.R.M. }\end{array}$} & \multicolumn{2}{|c|}{ Caesarean Sections } & \multirow{2}{*}{ Total } \\
\hline & & & With Pitocin & Without Pitocin & \\
\hline Oestriol & 77 & 8 & $\begin{array}{c}\text { (a) Failed induc- } \\
\text { tion, dispro- } \\
\text { portion } \\
\text { (b) Foetal distress; } \\
\text { brow prcsen- } \\
\text { tation } \\
\text { (c) Footal distress; } \\
\text { disproportion } \\
\text { (d) Past obstetric } \\
\text { history; age; } \\
\text { failed induc- } \\
\text { tion }\end{array}$ & $\begin{array}{c}4 \\
\text { (a) Cord prolapse } \\
\text { (b) Unstable lie } \\
\text { (c) Severe } \\
\text { toxaemia; } \\
\text { failed } \\
\text { induction } \\
\text { (d) Age; foetal } \\
\text { distress }\end{array}$ & 8 \\
\hline $\begin{array}{l}\text { Stilb- } \\
\text { oestrol }\end{array}$ & 77 & 8 & $\begin{array}{l}\text { (a) Failed induction } \\
\text { (b) Uterine infec } \\
\text { tion; failed } \\
\text { induction }\end{array}$ & $\begin{array}{l}1 \\
\text { (a) Age; } \\
\text { toxaemia }\end{array}$ & 3 \\
\hline Placebo & 77 & 3 & $\begin{array}{c}2 \\
\text { (a) Dispropcrtion; } \\
\text { foetal distress } \\
\text { (b) Disproportion }\end{array}$ & $\begin{array}{l}\text { (a) Age; failed } \\
\text { trial of } \\
\text { labour } \\
\text { (b) Inertia } \\
\text { (c) Failed trial } \\
\text { of labour } \\
\text { (d) Placenta } \\
\text { praevia }\end{array}$ & 6 \\
\hline
\end{tabular}

Table III.-Pitocin Drips in Second Oestrogen Trial

\begin{tabular}{l|c|c|c|c|c}
\hline Tablet & $\begin{array}{c}\text { No. } \\
\text { of } \\
\text { Women }\end{array}$ & $\begin{array}{c}\text { Spon- } \\
\text { taneous } \\
\text { Onset } \\
\text { before } \\
\text { A.R.M. }\end{array}$ & $\begin{array}{c}\text { No. of } \\
\text { Women } \\
\text { at Risk of } \\
\text { Pitocin } \\
\text { Drip after } \\
\text { A.R.M. }\end{array}$ & $\begin{array}{c}\text { No. of } \\
\text { Women } \\
\text { Requiring } \\
\text { Pitocin } \\
\text { Drip after } \\
\text { A.R.M. }\end{array}$ & $\begin{array}{c}\text { Incidence } \\
\text { of } \\
\text { Pitocin } \\
\text { Drip in } \\
\text { Women } \\
\text { at Risk }\end{array}$ \\
\hline $\begin{array}{l}\text { Oestriol } \\
\begin{array}{c}\text { Stilb- } \\
\text { oestrol }\end{array}\end{array}$ & 77 & 8 & 69 & 16 & $23 \cdot 2 \%$ \\
Placebo & 77 & 8 & 69 & 14 & $20.3 \%$ \\
\hline
\end{tabular}

in the puerperium, nor could any effects such as breast enlargement or vaginal bleeding be found in the babies.

\section{Discussion}

We have found that the administration of either oestriol or stilboestrol failed to affect either the length of labour or the quality of uterine contractions as evidenced on clinical examination. This is in accordance with Jeffcoate's (1948) more recent view on the effect of oestrogens in established labour. The proportion requiring pitocin drip is slightly higher in the control cases than in the oestrogen-treated group. All differences between the groups are, however, well within the possibilities of chance variation and there is no doubt that, within the limits of our trial, oestrogens are of no therapeutic value in the induction of labour. It is possible that a different dosage scheme or route of administration might yield a contrary result. This is unlikely, since oestrogens are rapidly metabolized and inactivated in the liver and in other tissues, which may account for their failure to affect the uterine muscle. For this reason, intramuscular or intravenous administration would be unlikely to achieve a much better result ; nor would a longer period of treatment or larger dosage.

TABLE IV.-Average Induction-Delivery Interval and Length of Labour in Second Oestrogen Trial (Excluding Caesarean Sections and Spontaneous Rupture of Membranes)

\begin{tabular}{|c|c|c|c|}
\hline Tablet & Patient & $\begin{array}{l}\text { Average } \\
\text { Induction- } \\
\text { Delivery } \\
\text { Interval }\end{array}$ & $\begin{array}{l}\text { Average } \\
\text { Length } \\
\text { of } \\
\text { Labour }\end{array}$ \\
\hline Oestriol .. & 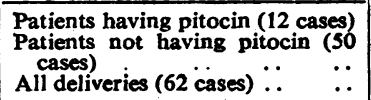 & $\begin{array}{l}42.58 \text { hours } \\
14.65 \text { ", } \\
20.06 ",\end{array}$ & $\begin{array}{l}13.51 \text { hours } \\
8.90, \\
9.79,\end{array}$ \\
\hline Stilboestrol & $\begin{array}{l}\text { Patients having pitocin (12 cases) } \\
\text { Patients not having pitocin ( } 55 \\
\text { cases) } \\
\text { All deliveries (67 cases) } \ldots\end{array}$ & $\begin{array}{l}37 \cdot 52 \text { hours } \\
14 \cdot 16 ", \\
18 \cdot 34 ",\end{array}$ & $\begin{array}{l}9 \cdot 23 \text { hours } \\
8 \cdot 54 \Rightarrow \\
8 \cdot 67 "\end{array}$ \\
\hline Placebo & 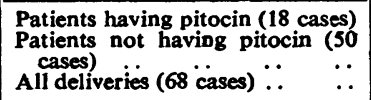 & $\begin{array}{l}40 \cdot 15 \text { hours } \\
15 \cdot 14 \text { ", } \\
21.76 \text { ", }\end{array}$ & $\begin{array}{l}8 \cdot 82 \text { hours } \\
9 \cdot 23 \text { ", } \\
9 \cdot 12 \text { " }\end{array}$ \\
\hline
\end{tabular}

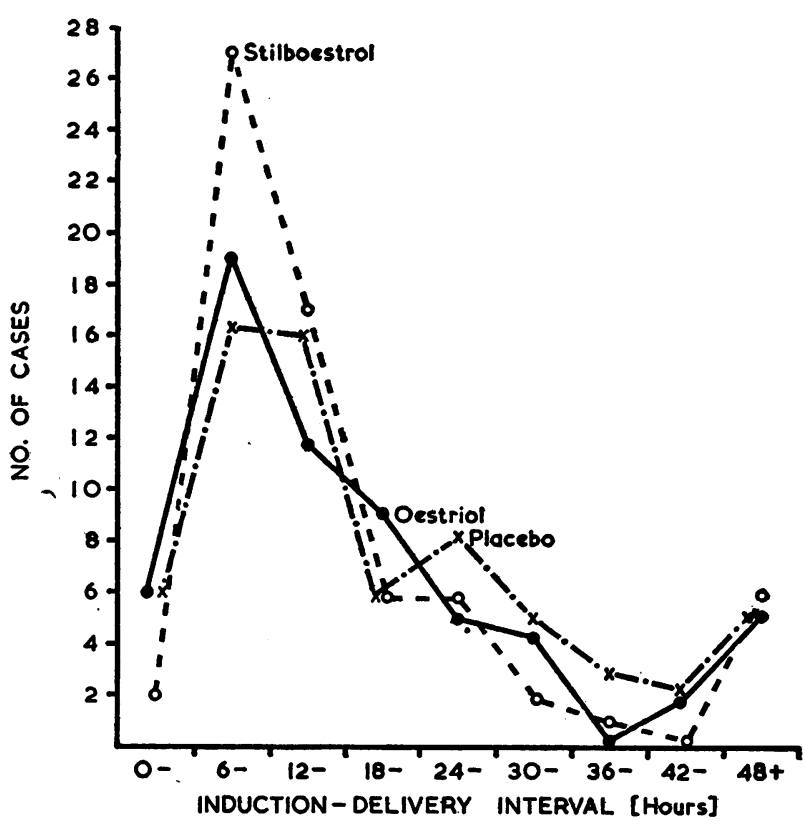

Induction-delivery interval in non-operative deliveries treated with oestriol, stilboestrol, or placebo tablets. 
Kelly (1961) has shown that the intravenous administration of oestrogen does not affect spontaneous uterine motility. It is likely that it is the concentration of active oestrogen in the uterine muscle which matters. In this event the only effective route of administration may be into the utero-placental space or into the amniotic cavity. The possibility of intra-amniotic injection is foreshadowed by the work of Diczfalusy et al. (1961) on the metabolism of intra-amniotic oestrogens, and we propose to extend our trials using this route.

\section{Summary}

A controlled trial was done on the effect of oral oestriol or stilboestrol in women who were to be subjected to artificial rupture of the membranes for surgical induction of labour. It was found that these oestrogens had no demonstrable effect on the inductiondelivery interval or on the length of labour.
We are grateful to our statistical colleagues $\mathrm{Mr}$. W. Z Billewicz and Miss R. Holliday for their help in the design of the trial and in dispensing tablets. Our thanks are due to the nursing staff at the Maternity Hospital for their co-operation, and to Dr. C. L. Hewett of the Organon Laboratories, for the gift of oestrogen and dummy tablets.

\section{REFERENCES}

Csapo, A. (1956). Amer. J. Anat., 98, 273.

Diczfalusy, E., Cassmer, O., Alonso, C., and Miquel, M. (1961) Acta Endocr. (Kbh.), 37, 353.

Jeffcoate, T. N. A. (1938). J. Obstet. Gynaec. Brit. Emp., 45, 893

(1948). Trans. Edin. obstet. Soc., p. 23.

Kelly, J. V. (1961). Amer. J. Obstet. Gynec., 82, 1207.

Klopper. A., Macnaughton, M. C., and Michie, E. A. (1961). J. Endocr., 22, XIV.

Reynolds, S. R. M. (1949). Physiology of the Uterus, 2nd ed. pp. 76-86 Hoeber Inc., New York.

Shearman, R. P. (1959). J. Obstet. Gynaec. Brit. Emp., 66, 1. Short, R. V., and Moore, N. W. (1959). J. Endocr., 19, 288.

\section{ALBRIGHT'S SYNDROME IN AN ADULT MALE REPORT OF AN ATYPICAL CASE WITH PSYCHIATRIC SYMPTOMS}

\section{P. HALL, M.B., Ch.B., D.P.M.}

\section{Foundation's Fund Research Fellow from the Department of Psychiatry, University of Sheffield}

The case of Albright's syndrome reported here is that of a man who at the age of 30 developed psychiatric symptoms culminating in an attempt at suicide. The syndrome consists of unilateral cutaneous melanosis and polyostotic fibrous dysplasia, accompanied by precocious puberty (Albright et al., 1937). It usually occurs in female children, and was probably first reported by Weil (1922). Its aetiology is unknown (Jolly, 1955). Correct differential diagnosis is simple (Cecil and Loeb, 1959) when the syndrome is kept in mind and may save fruitless surgical exploration for parathyroid adenomata. Thus, although the complete syndrome is rare (Murray et al., 1946), it is of practical importance, as well as of considerable theoretical interest. The incidence of other congenital abnormalities is apparently no greater in these patients than in the population at large (Vines, 1952), but many conditions have been found in association with the syndrome, among them coarctation of the aorta (Lichtenstein and Jaffe, 1942), acromegaly (Falconer et al., 1942), diabetes meilitus (Hurxthal and Musulin, 1953), and hyperthyroidism (Sternberg and Joseph, 1942). Some patients have been of subnormal intelligence (Albright et 'al., 1937). Pritchard (1951) reviews over one hundred papers on the clinical, radiological, and histological features of the condition, but only a small number of male cases have been recorded. Very few of these were adult; fewer still showed the complete syndrome, and none were reported as fertile. Some female patients with Albright's syndrome have borne children (Dockerty et al.,; 1945). The case reported below is thus in several respects atypical.

\section{Case History}

This patient was born on September 16, 1926, with a deformed forehead and a large brown birthmark on his left thigh. He developed normally and was well in every way until 1939, when he complained of a painful limp and a hard swelling on his left thigh. A diagnosis of osteitis fibrosa cystica was made, and a (histologically normal) parathyroid gland was removed. In August, 1940, radiographs showed small translucent cysts in the neck of the right and lower left femur. There was also a large cyst in the upper left femur. He continued to limp slightly until 1942 , when this symptom became worse, and he was found to have developed a pathological fracture of the left femoral neck. An osteotomy was performed, and some months later the parathyroid region was explored again, but no tumour was found.

The patient was employed as a storekeeper with the same firm from the age of 16 . He worked regularly until 1956, when he became increasingly depressed and anxious, and unable to work. He became oversensitive about his appearance and would not leave the house. In 1956 he had a course of electric convulsion therapy without much effect. In 1959 his wife gave birth to a son. He had by then been out of work for three years, felt he would be a failure as a father, and just before the birth of his son he made an attempt at suicide with barbiturates. In January, 1961, he was referred to the Sheffield University Department of Psychiatry, and the diagnosis of polyostotic fibrous dysplasia first put forward in 1943 was confirmed radiologically. Psychological testing showed average intelligence (Wechsler), and there was no sign of organic nervous disease.

The patient displayed the features of a chronic anxiety state with depression. His neurotic symptoms appeared to be related to his long-standing selfconsciousness over his deformities. He had the feeling that the two halves of his body were different. He felt his left side to be "all wrong" and his right side "all good." He worried about his facial and testicular asymmetry, spending much time in front of the mirror. He developed a stammer and a left facial tic, and hid in the attic when strangers called. He thought his condition to be unique and possibly even a divine punishment. His mother, an epileptic, had always overprotected him and dominated the household. He and his family lived with her and he felt continually torn between his dependence on her and his responsibilities to his wife and child. He was given psychotherapy over a period of four weeks (twelve sessions of three-quarters of an hour each). In the course of psychotherapy he was able to ventilate his feelings for the first time and he gained considerable insight into them. When he was discharged after seven weeks he was free from psychiatric symptoms. He had found himself a job as a hospital porter and took it up a few days after his 